\title{
Sensitivity to climate change of the mass balance of glaciers in southern Norway
}

\author{
TRON LAUMANN \\ Norwegian Water Resources and Energy Administration, N-0301 Oslo, Norway \\ NIELS REEH \\ Danish Polar Center/The Geological Survey of Greenland, DK-1350 Copenhagen K, Denmark
}

\begin{abstract}
A degree-day model developed for parameterizing melt rates on the Greenland ice sheet is adapted to the climatic conditions on glaciers in southern Norway. The model is calibrated by means of observed average mass-balanceelevation relationships (1963-90) for three glaciers in a west-east transect in southern Norway and 30 year normals (1961-90) of temperature and precipitation observed at nearby climate stations. The calibration gives a surprisingly small variation of the model parameters (degree-day factors for snow- and ice-melt, and precipitationelevation gradient) from one glacier to another. The derived values of the parameters are used to estimate the change of the mass-balance-elevation relationship for different climatic scenarios. The study indicates that a low-lying glacier in the maritime, high-precipitation environment near the Atlantic coast is more sensitive to both temperature and precipitation changes than the high elevated glaciers in the dry, more continental climate farther away from the coast. However, all of the glaciers studied will lose mass in a warmer climate, unless the warming is accompanied by a dramatic increase in the precipitation of $25-40 \% \mathrm{deg}^{-1}$ warming.
\end{abstract}

\section{INTRODUGTION}

The mass balance at the surface of a glacier (the net effect of annual snow-accumulation rate and annual melt rate) results from quite complex processes, involving the general atmospheric circulation and the energy balance at the ice-sheet surface. The modelling of these processes requires knowledge of a large number of variables as, for example, short-wave radiation, long-wave radiation, surface albedo, wind speed and direction, air and surface temperatures, humidity and precipitation. These variables must be obtained by means of comprehensive observational programmes. A number of energy-balance studies have been carried out in the past on glaciers in Norway (Liestøl, 1967; Messel, 1985). These studies have provided important information about the processes which determine the melt rates on different glaciers. However, when it comes to estimating the mass balance of a glacier, energy-balance methods have an obvious drawback because, in general, many of the variables needed for the calculations have not been observed and therefore must be estimated.

Consequently, there are good reasons for looking for a simpler approach as, for example, parameterizing the surface mass balance in terms of a few climatic parameters. The commonest of these simple models is the so-called degree-day model, which relates the melt rate to the air temperature. Hence, degree-day models do not describe the physics of the melt process but the melt rate is directly correlated with temperature. It is not feasible to apply degree-day models for calculating daily melt rates. However, in general, degree-day models give acceptable results when applied over longer periods of time. The reason is that many of the factors determining the melt process are correlated with temperature.

In this paper, a degree-day model is used to parameterize the mass balance as a function of elevation for three glaciers in southern Norway, i.e. Ålfotbreen, Nigardsbreen and Hellstugubreen. These glaciers are located along a west-east transect from the humid, marine environment on the Atlantic coast to the dry, continental environment $200 \mathrm{~km}$ farther to the east (see Fig. 1). The mass balance of these glaciers has been observed from 1963 until the present. The model to be used is that developed by Reeh (1991) with the purpose of estimating melt rates on the Greenland ice sheet. However, modifications have been introduced in order to adapt the model to the climate in southern Norway.

The main purpose of this work is to develop a massbalance model for glaciers in Norway which depends only on a few climatic parameters, with the aim of studying the effect of climatic change on the mass balance of the glaciers. Another purpose is to develop a simple massbalance model which can be used to force ice-dynamic models with the aim of estimating the response of Norwegian glaciers to climatic change (study in preparation by $\mathrm{T}$. Jóhannesson and T. Laumann). 


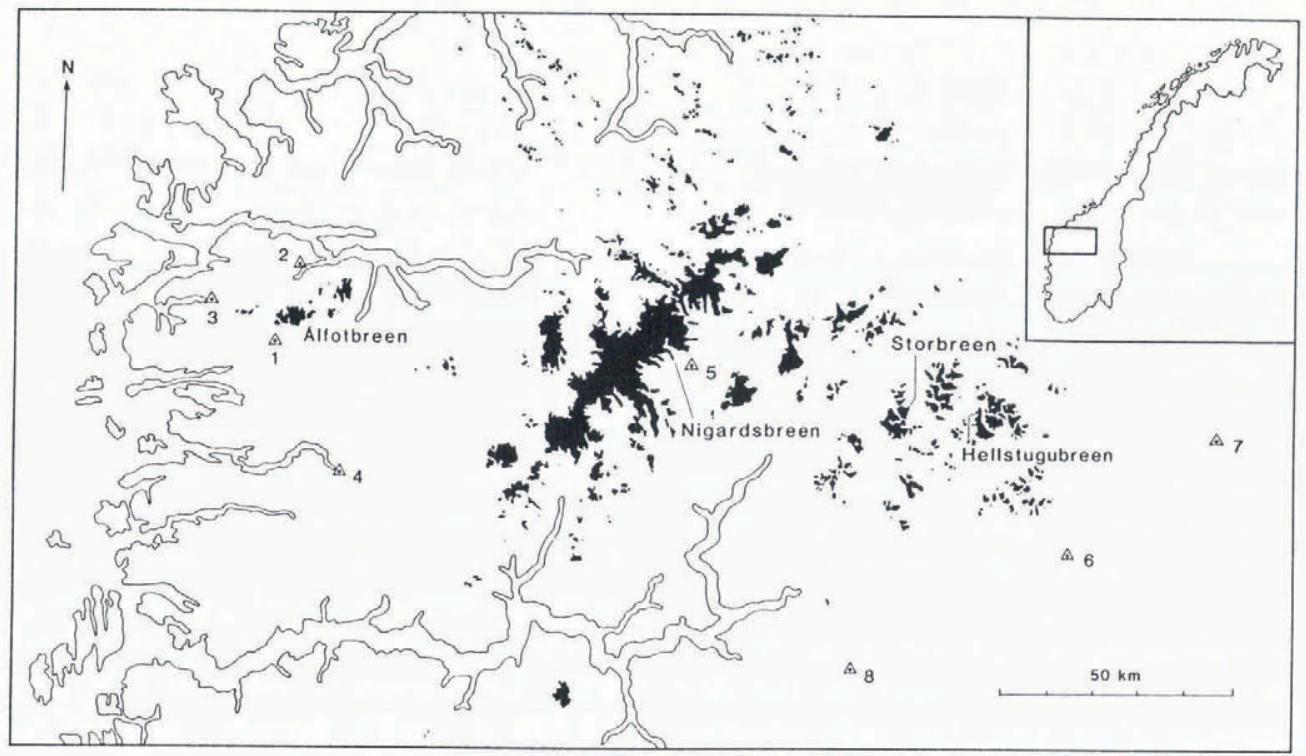

Fig. 1. Map showing location of glaciers and climatic stations. Climatic stations. 1, Grendalen; 2 Ålfoten II; 3, Svelgen; 4, Forde; 5, Bjørkehaug; 6, Bygdin; 7, Skåbu; 8, Fillefjell.

\section{DESGRIPTION OF THE MODEL}

A detailed description of the melt-rate model has been given by Reeh (1991). Therefore, in the following, only a brief description will be given, emphasizing the modifications introduced in order to adapt the model to the climatic conditions in southern Norway.

\subsection{The degree-day calculation}

The degree-day calculation is illustrated in Figure 2. The annual temperature cycle is approximated by a cosine function

$$
\mathrm{TD}=\mathrm{TMA}+\mathrm{AMP} \cos (2 \pi t / A+\phi)
$$

where, TMA is the long-term mean annual temperature, AMP is the amplitude of the long-term average annual temperature cycle, TD is the daily mean temperature, $t$ is time, $A=1$ year and $\phi$ is the phase angle.

Equation (1) gives a very good representation of the 30 year temperature normals for the climate stations near the glaciers with root-mean-square deviations between 0.4 and $0.6 \mathrm{~K}$. The climate stations used as temperature stations are Førde, Bjørkehaug and Skåbu for Ålfotbreen, Nigardsbreen and Hellstugubreen, respectively (see Fig. 1). The input to the model is 30 year average annual temperature cycles in terms of mean monthly temperatures, from which TMA, TMA and $\phi$ are determined by means of least-squares fitting. In order to account for temperature deviations from the long-term annual cycle, a stochastic term has been introduced. This is important for the degree-day calculation, since random temperature fluctuations in the spring or in the fall (maybe even in the winter) will cause positive temperatures, even though the long-term average temperature in these seasons is way below the freezing point. Moreover, although the daily temperature cycle contains a large deterministic component, it can also be accounted for by the stochastic term. In the model, the combined effect of these two terms on the calculation of positive degree-days is approximated by a statistic, which is normally distributed, centred on the curve given by Equation (1) and with a standard deviation $\sigma$ (see Fig. 2). This approach follows that suggested by Braithwaite (1985).

The positive degree-days in 1 year can therefore be calculated as

$$
\mathrm{PDD}=\int_{0}^{\infty}\left(T\left(\int_{0}^{A} \frac{1}{\sigma \sqrt{2 \pi}} \mathrm{e}^{-(T-\mathrm{TD})^{2} /(2 \sigma)^{2}}\right) \mathrm{d} t\right) \mathrm{d} T
$$

where TD is given by Equation (1) and $A=1$ year.

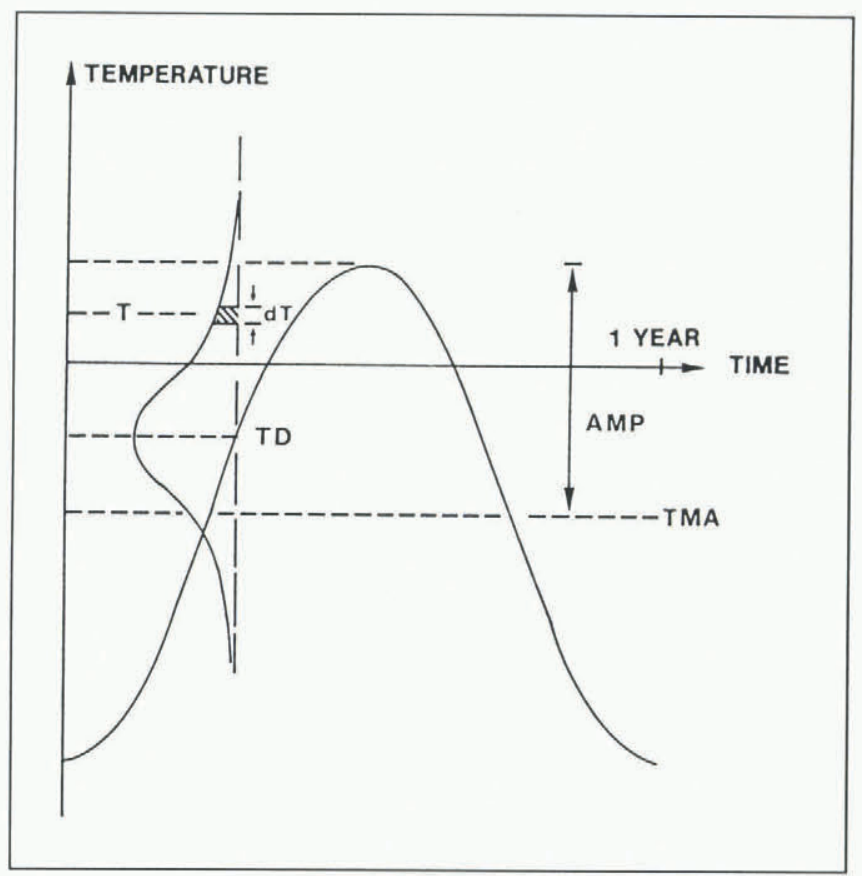

Fig. 2. Annual temperature variation used to calculate the number of positive degree-days per year. TD represents the long-term average daily temperature, TMA is the longterm mean annual temperature, $A M P$ is the amplitude of the long-term average annual cycle. See text for further information. 
In order to calculate the positive degree-days at different elevations, TD must be determined as a function of elevation. This is done by adjusting temperatures observed at the climate stations to higher elevations, using a constant lapse rate (see section 3 ).

The degree-day calculation by means of Equation (2) is tested using data from the climate station Bjørkehaug in Jostedalen (see Fig. 1) for the period 1964-82. During this period, temperature was recorded three times a day, viz. at 0700,1300 and $1900 \mathrm{~h}$. In addition maximum and minimum temperatures were observed, i.e. a total of five observations $\mathrm{d}^{-1}$. By means of these data, positive degreedays were summed for each year and the average annual positive degree-days in the period were calculated as $2035 \mathrm{Kd}$.

Next, mean temperatures for each day in the 19 year period (1964-82) were calculated based on the five temperature observations per day. For each calendar day of the year, the average of the resulting 19 mean daily temperatures could then be determined. These average mean daily temperatures were taken to represent the long-term annual temperature cycle. The average annual standard deviation of the observed temperature deviations from this long-term annual temperature cycle is $\sigma=4.4 \pm 0.8 \mathrm{~K}$ and contains a contribution from the daily temperature cycle (five observations per day) as well as a contribution from random temperature deviations from the long-term average annual cycle (19years of observation). This standard deviation, therefore, represents the standard deviation $\sigma$ used in Equation (2).

In Figure 3, positive degree-days (PDD) calculated by means of Equation (2), with TD determined by using the Bjørkehaug 1964-82 long-term annual temperature cycle, are plotted against $\sigma$. PDD $=2035 \mathrm{Kd}$ corresponds to $\sigma=4.6 \mathrm{~K}$, in good agreement with the $\sigma$ value of $4.4 \pm 0.8 \mathrm{~K}$ calculated from the detailed data. This

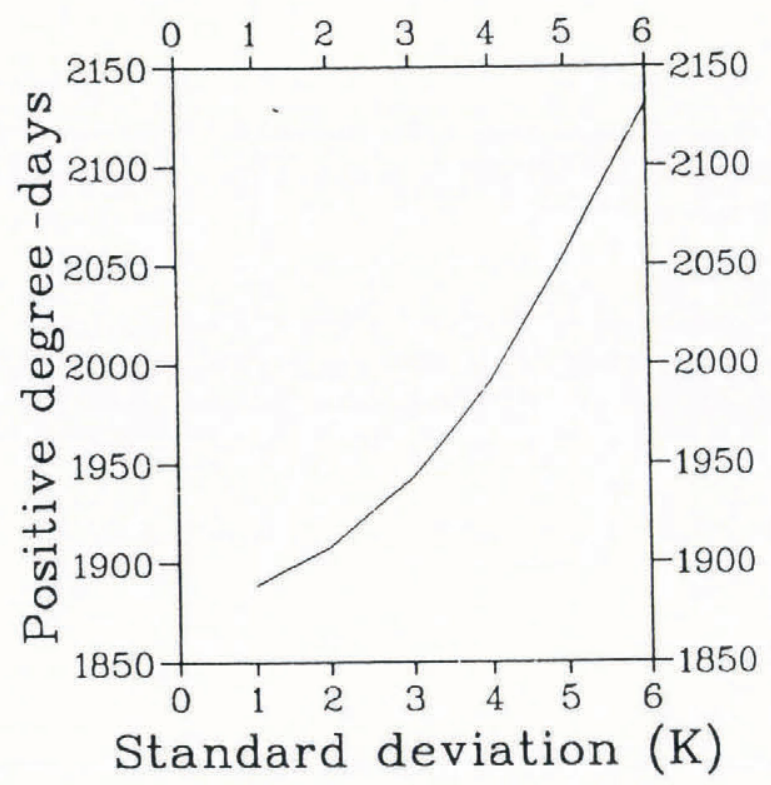

Fig. 3. Positive degree-days calculated by means of the model for the period 1964-82 at Bjorkehaug, using different standard deviations. The dotted line corresponds to the positive degree-days (2035) calculated by using daily observations in the same period. The corresponding standard deviation is $4.6 K$. confirms that the statistical approach can be used as a good approximation for calculating positive degree-days, as previously demonstrated by Braithwaite (1985). Also, it is worth mentioning that the $\sigma$ values found above are in very good agreement with the value of $4.5 \mathrm{~K}$ suggested by Reeh (1991) for degree-day calculations in Greenland.

\subsection{Snow and ice melt}

The positive degree-days as calculated by means of Equation (2) are used to melt snow and ice as follows: snow, if present, is melted. The meltwater percolates into the snow cover where it may refreeze as superimposed ice. Run-off does not begin until the cold storage of the winter snow has been eliminated. In the model this process is not followed in detail. Instead, run-off is assumed not to start until the amount of refrozen melt (superimposed ice) exceeds a certain fraction $\left(P_{\max }\right)$ of the winter snow accumulation. The value of $P_{\max }$ should be chosen considering the freezing potential of the snow layer at the end of the winter season. For the Greenland study (Reeh, 1991), a value of $P_{\max }=0.6$ appeared to be appropriate. For glaciers in southern Norway, the freezing potential of the winter-snow cover is much lower and can be neglected (Laumann, unpublished). Accordingly, in this study, $P_{\max }$ is set equal to zero.

If the positive degree-days exceed the number needed for melting the snow, the remaining degree-days are used to melt glacier ice, but with a different degree-day factor (see section 3).

\subsection{Precipitation}

In the original version of the melt model, which was designed for Greenland ice-sheet conditions, it was assumed that the total annual precipitation fell in the form of snow. This may be a reasonable assumption for the Greenland ice sheet but certainly not for the precipitation on the glaciers in Norway. Therefore, modifications to the model have had to be introduced to allow calculation of the fraction of the annual precipitation that falls as snow at different elevations.

In general, the available climatic data will be monthly mean values of temperature and precipitation measured at one or more climate stations near the glacier. The input data needed for the mass-balance calculation, however, are the annual temperature cycle and the total annual snow precipitation as a function of elevation. Temperature and precipitation are therefore adjusted to higher elevations by means of constant elevation gradients (see section 3). Experience from Norwegian glaciers shows that precipitation will fall as snow, even for a small positive temperature $\left(\mathrm{TS}=1^{\circ} \mathrm{C}\right)$. Therefore, the annual snow accumulation is determined as the precipitation falling in the season when the temperature is below TS. The calculation is performed by using monthly mean values of temperature and precipitation at various elevations. To account for the error that would be introduced if the total precipitation in a month with a mean temperature slightly above or below TS was counted as either rain or snow, temperatures are assumed to be normally distributed around the mean monthly temperature with standard deviation $\sigma_{\mathrm{M}}$. The 
fraction of the total monthly precipitation that falls as snow is then determined as the fraction of the month with temperatures below TS.

This method of calculating the snow accumulation is tested by means of the above-mentioned data from Bjørkehaug. The model-calculated snow accumulation at different elevations is compared with the snow accumulation determined by means of daily observations of temperature and precipitation in the period 1964-81, (see Fig. 4). In the test, the elevation gradient of the precipitation is neglected, so that the amount of snow falling at a given elevation is only dependent on the temperature. The standard deviation $\sigma_{M}$ is determined as the standard deviation of the daily mean temperatures from the mean monthly temperatures in the period 1964 82. This standard deviation $(3.6 \mathrm{~K})$ should not be mistaken for the standard deviation $\sigma$ used in the degree-day calculation (see section 2.1).

The full curve in Figure 4 represents the snow accumulation calculated by using daily observations of temperature and precipitation, whereas the dotted curve represents the snow accumulation calculated by means of the model described above using the statistical approach. Although the dotted curve gives a reasonable estimate of the snow accumulation, it obviously overestimates the snow accumulation in the lower reaches and underestimates the snow accumulation in the upper reaches. The explanation is that, in the winter, the temperature is generally higher on a day with precipitation than it is on a "dry" day. In the summer, on the contrary, the

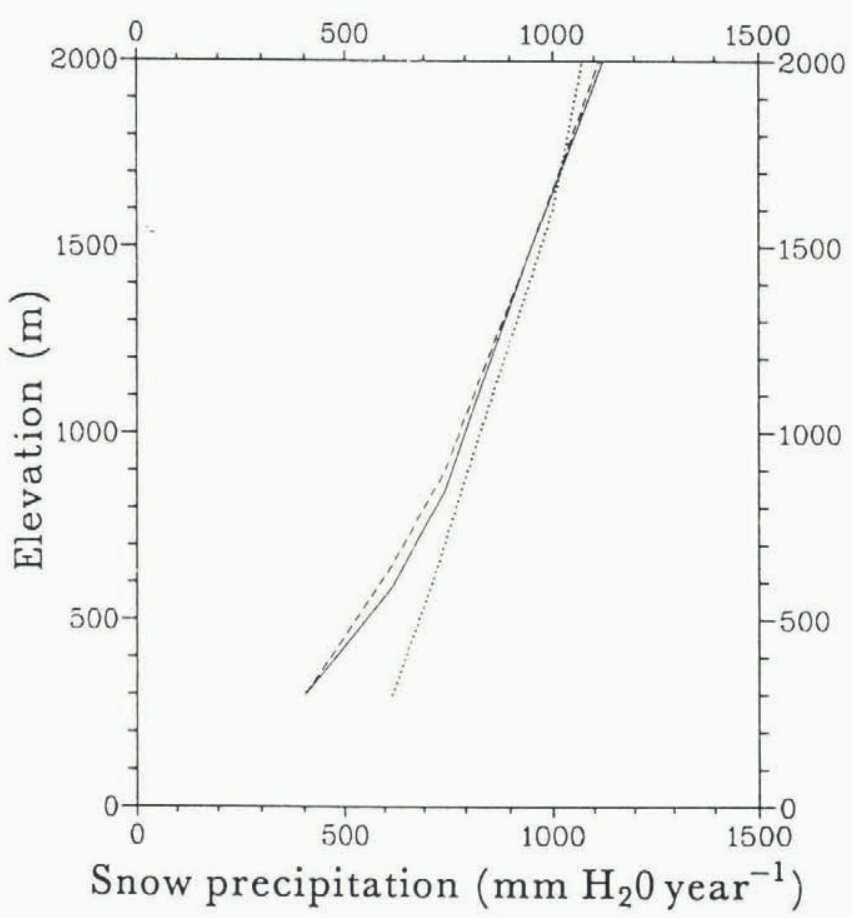

Fig. 4. Snow precipitation as a function of elevation as calculated by means of the model (dashed and dotted curves) compared with calculations using daily observations (solid line) at Bjorkehaug for the period 1964-82. The elevation gradient of the precipitation is set to zero. The dotted line results when mean monthly temperatures are used for estimating the snow precipitation. The dashed line is the result when monthly mean temperatures for days with precipitation are used. temperature is generally lower on a day with precipitation than it is on a "dry" day. This means that, in the winter season, a lower proportion of the precipitation will fall as snow in the lower reaches of the glacier than estimated when using mean monthly temperatures, whereas the use of mean monthly temperatures gives essentially correct estimates for the upper reaches of the glacier. In the summer season, conditions are reversed: a higher proportion of the precipitation will fall as snow in the upper reaches of the glacier than estimated when using mean monthly temperatures, whereas the use of mean monthly temperatures gives essentially correct estimates for the lower reaches of the glacier.

If the calculation is based on mean monthly temperatures determined for days with precipitation only (dashed curve in Fig. 4), a very close fit to the snow-accumulation curve as determined by means of the detailed data (full curve in Fig. 4) is obtained.

Unfortunately, temperature statistics for days with precipitation are not generally available. A simple approximate way of accounting for the fact that the temperature on a day with precipitation is different from the temperature on a "dry" day would be to reduce the amplitude (AMP) of the fitted annual temperature cycle given by Equation (2) by $1-2 \mathrm{~K}$. This would have the desired effect of lowering summer temperatures and increasing winter temperatures. (For the degree-day calculation, the full temperature amplitude should, of course, be used.) However, in view of the uncertainties of the other model parameters (i.e. degree-day factors, temperature-elevation gradients, precipitation-elevation gradients), mean monthly temperatures will be used in this work to calculate the fraction of the total precipitation which falls as snow.

\section{MODEL PARAMETERS}

Before the mass-balance model can be used to predict mass-balance changes under different climatic conditions, the model parameters must be determined. For this purpose average mass-balance-elevation data for the period 1963-90 from Ålfotbreen, Nigardsbreen and Hellstugubreen are used. The climate data to be used are 30 year normals for the period 1961-90 from different climate stations near the glaciers (for location, see Fig. 1). Hence, the study area covers a region in southern Norway with a strong climatic gradient from the humid, marine environment on the Atlantic coast to the dry continental environment $200 \mathrm{~km}$ farther to the east.

There is a small difference of 2 years (1961 and 1962) between the period covering the mass-balance observations and the period covering the climate observations. However, data published by Roland and Haakensen (1985) suggest that the average temperature of the years 1961 and 1962 is very close to the 30 year normal for the period 1961-90. This probably means that only a small error will be introduced by using the 1961-90 climatic normals.

In addition to observations of temperature and precipitation at climate stations near the glaciers, the following parameters need to be determined: temperature lapse rate, degree-day factors for snow and ice melt and the precipitation-elevation gradient (Table 1). The 


\begin{tabular}{lccc} 
Lat. (N) & $61^{\circ} 45^{\prime}$ & $61^{\circ} 41^{\prime}$ & $61^{\circ} 34^{\prime}$ \\
Long. (E) & $05^{\circ} 39^{\prime}$ & $07^{\circ} 11^{\prime}$ & $08^{\circ} 27^{\prime}$ \\
$\begin{array}{l}\text { Temperature } \\
\text { gradient }(\mathrm{K} / 100 \mathrm{~m})\end{array}$ & -0.70 & -0.75 & -0.75 \\
$\begin{array}{c}\text { Precipitation } \\
\text { gradient (\%/100 m) }\end{array}$ & 7 & 8 & 7 \\
$\begin{array}{l}\text { Degree-day factor } \\
\text { snow melt } \\
\text { (mm K } \mathrm{K}^{-1} \text { ) }\end{array}$ & 4.5 & 4.0 & 3.5 \\
$\begin{array}{c}\text { Degree-day factor ice } \\
\text { melt }\left(\mathrm{mm} \mathrm{K}^{-1} \mathrm{~d}^{-1} \text { ) }\right.\end{array}$ & 6.0 & & \\
\hline
\end{tabular}

values used for the standard deviations $\sigma$ and $\sigma_{\mathrm{M}}$, and the quantity $P_{\max }$, are specified in section 2 .

\section{1. Ålfotbreen}

Of all the glaciers in Norway, Alfotbreen is the one that is located in the most maritime environment. The precipitation in this region is very large (more than $3000 \mathrm{~mm}$ year $^{-1}$ at sea level and more than $5000 \mathrm{~mm}$ year $^{-1}$ in the coastal mountains), and the precipitation varies strongly from place to place dependent on local conditions. In this study, the precipitation at sea level near Alfotbreen is therefore determined as the average of the observations at three stations located around the glacier, i.e. Svelgen, Grøndalen and Ålfoten (see Fig. 1). The temperature data are taken from the climate station at Førde.

The determination of the model parameters is impeded by the fact that almost identical results can be obtained with more than one choice of model parameters. Consequently, it is important to restrain as many of the parameters as possible by means of observed quantities before attempting to fit the remaining parameters.

Beside the mass-balance, the temperature at the front of Allfotbreen has been measured in the period 1965-81. For this period, the average temperature lapse rate in the summer season June-September from Førde at an elevation of $11 \mathrm{~m}$ to the glacier front at about $900 \mathrm{~m}$ elevation was $-0.73 \pm 0.02 \mathrm{~K} / 100 \mathrm{~m}$. The summer lapse rate ranges between $-0.78 \mathrm{~K} / 100 \mathrm{~m}$ for June and $-0.64 \mathrm{~K} / 100 \mathrm{~m}$ for September. Using an average temperature lapse rate of $-0.7 \mathrm{~K} / 100 \mathrm{~m}$, the $1961-90$ average annual temperature cycle at Førde, and the observed winter balance on the glacier as input, the remaining unknown parameters are the degree-day factors for snow and ice melt. The best-fit values of these parameters are determined by comparing model-calculated - and observed elevation profiles of average summer - and net balances for the period 1961-90 (see Fig 5a). The best-fit
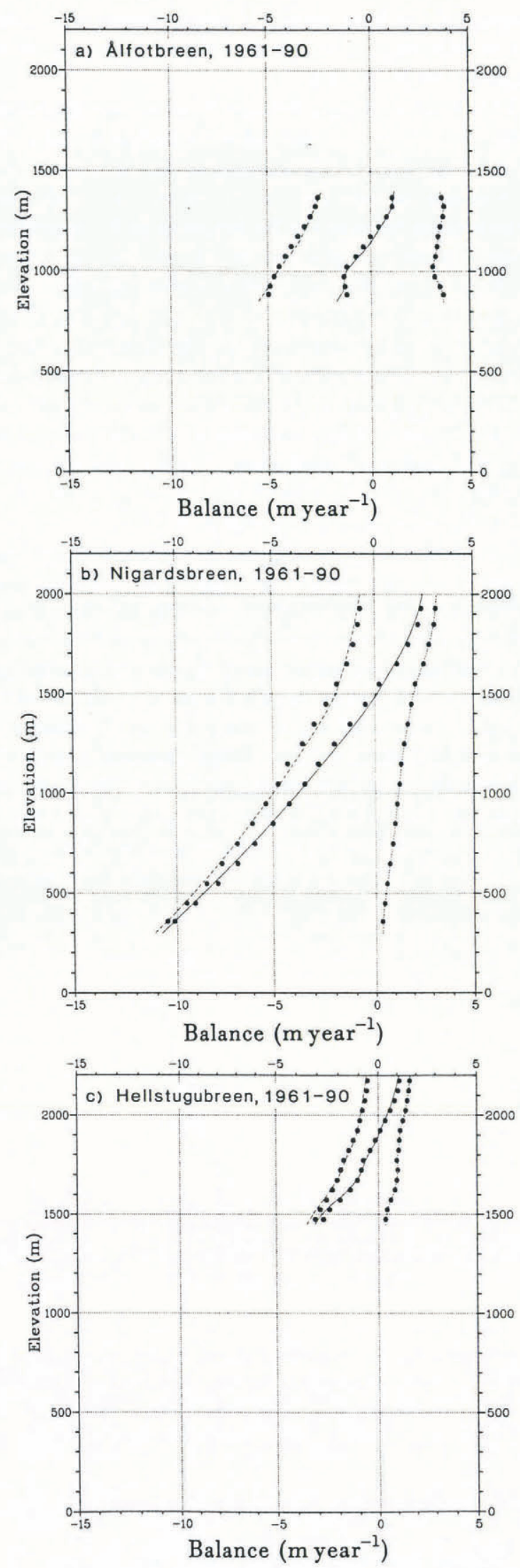

Fig. 5. Calculated mass balance (dashed and solid lines) for the period 1961-90 and observed mass balance (large dots) for the period 1963-90 as a function of elevation for (a) Alfotbreen, (b) Nigardsbreen and (c) Hellstugubreen. Input data for the calculations are the observed winter balances (dotted lines) and mean monthly temperatures at (a) Forde, (b) Bjorkehaug and (c) Skabu (for location see Fig. 1). For other parameter values, see Table 1. Legend. - - - summer balance; - net balance; .... winter balance. 
values of the degree-day factors are $4.5 \mathrm{~mm}$ of $\mathrm{H}_{2} \mathrm{O} / \mathrm{PDD}$ and $6 \mathrm{~mm}$ of $\mathrm{H}_{2} \mathrm{O} / \mathrm{PDD}$ for snow and ice melt, respectively.

Measurements done on Ålfotbreen by Norges Vassdrags- og Elektrisitetsvesen (NVE) in 1965 gave degreeday factors of $5.3 \mathrm{~mm}$ of $\mathrm{H}_{2} \mathrm{O} / \mathrm{PDD}$ at the equilibrium line and $7.5 \mathrm{~mm}$ of $\mathrm{H}_{2} \mathrm{O} / \mathrm{PDD}$ on the glacier tongue. These values and other degree-day factors obtained by measurements on Norwegian glaciers will be discussed in section 3.4 .

The last step in the determination of the model parameters is to introduce the observed precipitation at climate stations near Alfotbreen instead of the observed winter balance and use the method described in section 2.3 to calculate the snow precipitation as a function of elevation. A good fit to the observed winter, summer and net balances at elevations above $1000 \mathrm{~m}$ is obtained by using a precipitation gradient of $7 \%$ increase per $100 \mathrm{~m}$. The results are presented in Figure 6a. The difference between observed and calculated winter balances above $1350 \mathrm{~m}$ elevation and below $1000 \mathrm{~m}$ elevation can probably be explained as being caused by wind transport of snow from the upper to the lower reaches of the glacier. This process is not included in the model. Nevertheless, the overall fit between model results and observations is satisfactory.

\subsection{Nigardsbreen}

For the mass-balance modelling on Nigardsbreen, temperature and precipitation as observed at the nearby climate station Bjørkehaug are used. The temperature lapse rate in the area can be estimated from temperature observations at Bjørkehaug ( $324 \mathrm{~m}$ a.s.l.) and Steinmann ( $1630 \mathrm{~m}$ a.s.l.) for the period $1965-81$. The average lapse rate for the summer months June, July and August was $-0.75 \pm 0.01 \mathrm{~K} / 100 \mathrm{~m}$ ranging between $-0.78 \mathrm{~K} / 100 \mathrm{~m}$ for June and $-0.72 \mathrm{~K} / 100 \mathrm{~m}$ for August. Using the average temperature lapse rate of $-0.75 \mathrm{~K} / 100 \mathrm{~m}$, the 1961-90 average annual temperature cycle for Bjørkehaug and the observed winter balance on Nigardsbreen as input, a good fit to the observed summer and net balance curves is obtained with degree-day factors of $4 \mathrm{~mm}$ of $\mathrm{H}_{2} \mathrm{O} / \mathrm{PDD}$ for snow melt and $5.5 \mathrm{~mm}$ of $\mathrm{H}_{2} \mathrm{O} / \mathrm{PDD}$ for ice melt (see Fig. 5b). These values are slightly lower than the degree-day factors found for Alfotbreen. The explanation is probably that higher wind speeds and humidity in the maritime environment at Alfotbreen result in a larger melting effect for the same temperature.

In Figure 6b, observed and model-calculated winter, summer and net balances are compared. In these calculations, the observed winter balance on the glacier is replaced by the snow accumulation determined from the observed precipitation at Bjørkehaug by means of the calculation method described in section 2.3. The good fit in Figure $6 \mathrm{~b}$ is obtained by using a precipitation gradient of $8 \%$ increase per $100 \mathrm{~m}$. The fit would have been even better if the monthly mean temperatures used to calculate the fraction of the precipitation falling as snow were replaced by monthly mean temperatures for periods with precipitation only (see discussion in section 2.3 and Figure $4)$.
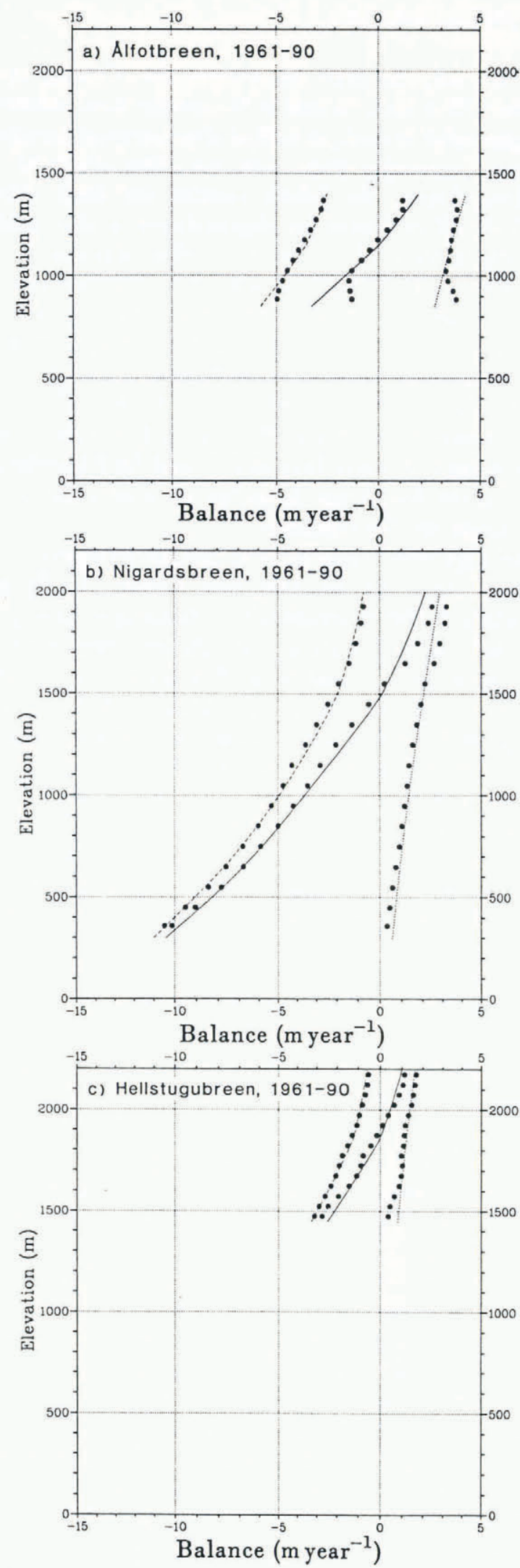

Fig. 6. Calculated mass balance (dashed and solid lines) for the period 1961-90 and observed mass balance (large dots) for the period 1963-90 as a function of elevation for (a) Alfotbreen, (b) Nigardsbreen and (c) Hellstugubreen. Input data for the calculations are mean monthly temperatures at (a) Forde, (b) Bjorkehaug and (c) Skåbu, and the mean monthly precipitation at (a) Allfoten II, Grendalen and Svelgen (average), (b) Bjorkehaug and (c) Bygdin (for location see Fig. 1). For other parameter values, see Table 1. Legend. - - - summer balance; - net balance; .... winter balance. 


\subsection{Hellstugubreen}

For the mass-balance calculations for Hellstugubreen, Skåbu ( $865 \mathrm{~m}$ a.s.l.) is used as the temperature station and Bygdin (1055 m a.s.l.) is used as the precipitation station. Temperature-lapse rates have not been observed near Hellstugubreen, for which reason the lapse rate of $-0.75 \mathrm{~K} / 100 \mathrm{~m}$ found for Nigardsbreen is also used for Hellstugubreen. The result of the calculation with application of the 1961-90 average annual temperature cycle for Skåbu and the observed winter balance on Hellstugubreen is shown in Figure 5c. A good fit to the observed summer and net balances is obtained with degree-day factors of 3.5 and $5.5 \mathrm{~mm} \mathrm{H}_{2} \mathrm{O} / \mathrm{PDD}$ for snow and ice melt, respectively. The degree-day factor for snow melt is slightly lower than that found for Nigardsbreen, whereas the degree-day factor for ice melt is the same as that found for Nigardsbreen.

In Figure 6c, observed and model-calculated winter, summer and net balances are compared. In these calculations, the observed winter balance on the glacier was replaced by the snow accumulation determined from the observed precipitation at Bygdin by means of the calculation method described in section 2.3. The good fit in Figure $6 \mathrm{c}$ is obtained by using a precipitation gradient of $7 \%$ increase per $100 \mathrm{~m}$. Also, for Hellstugubreen, the fit would have been even better if the monthly mean temperatures used to calculate the fraction of the precipitation which falls as snow were replaced by monthly mean temperatures determined for periods with precipitation only (see discussion in section 2.3 and Figure 4).

\subsection{Discussion of model parameters}

An overview of the derived parameters is given in Table 1. In general, the parameters show surprisingly little variation from one glacier to another. The temperature gradient is slightly higher (less negative) for Alfotbreen than for the other two glaciers, probably reflecting the more humid conditions near the Atlantic coast giving rise to more frequent overcast skies and more days with precipitation than in the more continental environment of the other two glaciers. The derived precipitation gradients are very similar and the small variation from $7 \%$ increase per $100 \mathrm{~m}$ to $8 \%$ increase per $100 \mathrm{~m}$ most likely reflects the influence of local topography, i.e. that precipitation at a station on the lee side of a mountain range, for example, Bjørkehaug at Nigardsbreen, is reduced compared to the regional average.

The degree-day factors for snow and ice melt decrease from west to east. The snow-melt factor ranges from 4.5 $\mathrm{mm} \mathrm{H}_{2} \mathrm{O} / \mathrm{PDD}$ in the west to $3.5 \mathrm{~mm} \mathrm{H}_{2} \mathrm{O} / \mathrm{PDD}$ in the east, whereas the ice-melt factor ranges from $6 \mathrm{~mm} \mathrm{H}_{2} \mathrm{O} /$ $\mathrm{PDD}$ in the west to $5.5 \mathrm{~mm} \mathrm{H}_{2} \mathrm{O} / \mathrm{PDD}$ in the east. The trends in the melt factors can very likely be explained as being due to higher wind speeds and humidity in the maritime environment in the west compared to the calmer and drier conditions in the east, causing higher melt rates for the same temperature in the west than in the east. This explanation is supported by table 10 of Roland and Haakensen (1985), which shows that the fraction of the ablation which is due to convection/ condensation decreases from $0.5-0.7$ on glaciers in western Norway to $0.3-0.4$ on glaciers farther to the east.

The derived values can be compared to degree-day factors obtained by measurements on different glaciers in Norway. As mentioned in section 3.1, measurements on Ålfotbreen by Norges Vassdrags- og Elektrisitetsvesen (NVE) in 1965 gave degree-day factors of $5.3 \mathrm{~mm} \mathrm{H}_{2} \mathrm{O}$ / $\mathrm{PDD}$ at the equilibrium line and $7.5 \mathrm{~mm} \mathrm{H}_{2} \mathrm{O} / \mathrm{PDD}$ on the glacier tongue. The corresponding numbers found by Pytte and Liestøl (1966) on Storsteinsfjellbreen i Nordland $\left(68^{\circ} 15^{\prime} \mathrm{N}, 17^{\circ} 54^{\prime} \mathrm{E}\right)$ are $5.6 \mathrm{~mm} \mathrm{H}_{2} \mathrm{O} / \mathrm{PDD}$ and $7.5 \mathrm{~mm} \mathrm{H}_{2} \mathrm{O} / \mathrm{PDD}$, respectively. In a measuring program from 1967 to 1974 on Fillefjell $\left(61^{\circ} 10^{\prime} \mathrm{N}, 08^{\circ} 07^{\prime} \mathrm{E}\right)$, Furmyr and Tollan (1975) found an average degree-day factor for snow melt of $3.9 \mathrm{~mm} \mathrm{H}_{2} \mathrm{O} / \mathrm{PDD}$. Finally, Liestøl (1967) calculated an average value for melting on Storbreen $\left(61^{\circ} 34^{\prime} \mathrm{N}, 08^{\circ} 08^{\prime} \mathrm{E}\right)$ in the period $1949-65$ of $5.5 \mathrm{~mm} \mathrm{H}_{2} \mathrm{O} / \mathrm{PDD}$.

It appears that the degree-day factors for snow melt derived in this study are in good agreement with the observations. However, the derived degree-day factors for ice melt are slightly lower than most of the values previously reported for Norwegian glaciers. The degreeday factors also deviate slightly from those found by observations on the ice margin in southwest Greenland (Braithwaite and Olesen, 1989). These authors found degree-day factors of $2.5 \mathrm{~mm} \mathrm{H}_{2} \mathrm{O} / \mathrm{PDD}$ and 7$8 \mathrm{~mm} \mathrm{H}_{2} \mathrm{O} / \mathrm{PDD}$ for snow and ice melt, respectively.

Part of the explanation for the low ice-melt factors derived in this study compared to the "observed" values could be that the latter are based on temperatures measured on, or very close to the locations where the melt rates were observed. This is in contrast to the present study in which the temperatures used for deriving meltrate factors are determined by means of observations at meteorological stations at some distance from the glaciers combined with measured or estimated temperatureelevation gradients. A small change in the temperature gradient will, for example cause a significant change in the melt-rate factors. As an illustration, scattered observations indicate that the temperature on the glacier tongue of Nigardsbreen at the same elevation as the nearby Bjørkehaug meteorological station is $1-2 \mathrm{~K}$ lower than the temperature measured at Bjørkehaug. If this temperature difference had been taken into account, a higher melt-rate factor (about $7 \mathrm{~mm} \mathrm{H}_{2} \mathrm{O} / \mathrm{PDD}$ ) would have been found. The reason why the derived snow-melt factor shows a better agreement with the observations is that the derivation of this factor, to a large extent, is based on the temperature conditions at the high elevated area of Nigardsbreen, which is close to the local Steinmann temperature station. The melt-rate factors derived in this study should therefore be considered as fitted to the temperature observations at the available meteorological stations.

\section{SENSITIVITY TO CLIMATE CHANGE}

Using the parameters listed in Table 1, the change in the mass-balance-elevation relationship is estimated for the three glaciers with different climatic scenarios. For a doubling of the atmospheric $\mathrm{CO}_{2}$ content (which could happen in the year 2030 (Houghton and others, 1990)), 
the increase of the temperature in southern Norway is estimated to be $1.5-3.5 \mathrm{~K}$, accompanied by an increase in precipitation of 7-8\% (Sælthun and others, 1990).

Simulations are made for temperature increases between 0 and $5 \mathrm{~K}$ with a step of $1 \mathrm{~K}$. For each of these temperature increases, the net-balance elevation relationship is calculated for three different precipitation scenarios: (1) unchanged precipitation, (2) a $20 \%$ increase and (3) a $40 \%$ increase, compared to the present. The results are illustrated in Figures $7 \mathrm{a}, \mathrm{b}$ and $\mathrm{c}$ and $8 \mathrm{a}, \mathrm{b}$ and c. Figure 7 shows calculated net-balance elevation relationships for the three glaciers for temperature increases of $1 \mathrm{~K}$ and $3 \mathrm{~K}$, respectively, and with three different changes of precipitation $(0,20$ and $40 \%$ ) for each temperature scenario. In this study, likely seasonal variations of the temperature and precipitation increases were not considered, although such variations have a significant influence on the results.

The calculated net-balance elevation relationships, corresponding to the present climate conditions (i.e. 1961-90 normals), are shown by the solid circles.

It appears, from Figure $7 \mathrm{a}$, that a temperature rise of $3 \mathrm{~K}$ will have a rather dramatic effect on Alfotbreen. The glacier is located at a relatively low elevation and is therefore highly sensitive to an increase in the temperature, which will not only cause increased melting but also cause a relatively higher proportion of the precipitation (about $6 \%$ for a temperature increase of $1 \mathrm{~K}$ ) to fall as rain instead of snow. For a temperature increase of $3 \mathrm{~K}$, the equilibrium line will rise above the highest point of the glacier, unless, simultaneously, the precipitation increases by $30-40 \%$. Even a moderate temperature increase of $1 \mathrm{~K}$ will have to be accompanied by a precipitation increase of almost $30 \%$ in order to maintain the present status of the glacier (a small positive specific balance of $0.25 \mathrm{~m}_{\text {year }}{ }^{-1}$ ).

Nigardsbreen will manage better, although the equilibrium line will rise by $300 \mathrm{~m}$ from the present c. $1500 \mathrm{~m}$ to $\mathrm{c} .1800 \mathrm{~m}$ for a $3 \mathrm{~K}$ temperature increase and unchanged precipitation. Since a significant part of the present accumulation area of the glacier is located in this altitude range, this will have a larger impact on the balance of the glacier than immediately indicated by the mass-balance curves shown in Figure $7 \mathrm{~b}$. On the glacier tongue, the ablation will increase by up to $5 \mathrm{~m}$ year $^{-1}$. This will probably result in a steeper and more active glacier tongue. However, proper treatment of the response of the glacier to climatic change will require application of an ice-dynamic model using the massbalance history as input (paper in preparation by $\mathrm{T}$. Jóhannesson and T. Laumann). For the more moderate temperature scenario of a $1 \mathrm{~K}$ temperature increase, the glacier will manage reasonably well if precipitation increases by about $20 \%$, although the lower part of the glacier tongue will experience a significantly higher ablation than with the present climate.

On Hellstugubreen, the equilibrium line will also rise by about $300 \mathrm{~m}$ for a $3 \mathrm{~K}$ temperature increase, assuming unchanged precipitation compared to the present. This will probably result in a complete disappearance of the glacier in 50-100 years. For a more moderate temperature increase of $1-2 \mathrm{~K}$ and a precipitation increase of $10 \%$, the glacier is likely to experience only a moderate retreat. In
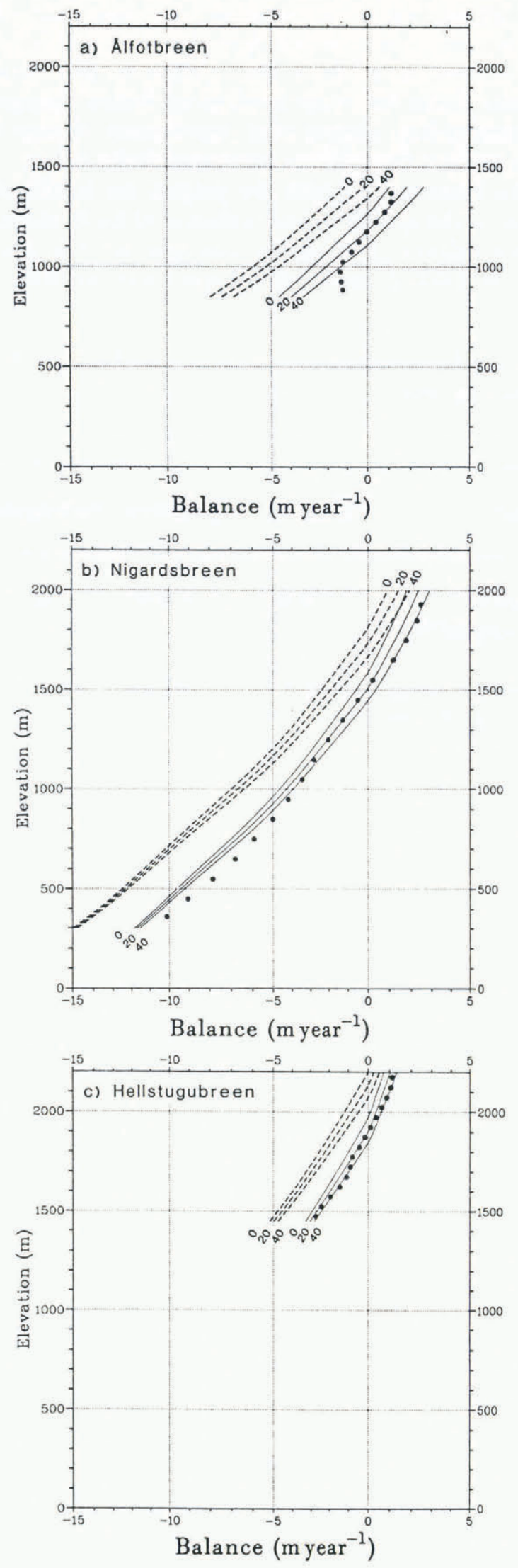

Fig. 7. Calculated net balances for different climate scenarios compared with observed net balance (dots) for the period 1963-90 at (a) Alfotbreen, (b) Nigardsbreen and (c) Hellstugubreen. In each panel, the three solid lines illustrate the net balance for a temperature increase of $1 K$ with different increases in precipitation (0,20 and 40\%). The three dashed lines illustrate the net balance for a temperature increase of $3 K$ with different increases of precipitation (0, 20 and 40\%). 
this connection, it is important to point out that Hellstugubreen is a valley/cirque glacier and therefore is less sensitive to a rise in the equilibrium line than a plateau glacier for which a relatively limited change of equilibrium-line altitude may significantly change the ratio between the ablation and accumulation areas.

An important quantity for judging the health of a glacier is the specific annual balance, which is the total annual balance of the glacier averaged over the glacier area. In Table 2, the calculated specific annual balances

Table 2. Comparison of measured and calculated specific mass balances

Glacier Alfotbreen Nigardsbreen Hellstugubreen

Observed $+0.30+0.43$ $-0.25$ (mean 1963-90)

$\begin{array}{llll}\begin{array}{l}\text { Modelled (using } \\ \text { calculated winter }\end{array} & +0.45 & +0.26 & -0.16 \\ \text { balance) } & & \\ \begin{array}{l}\text { Modelled (using } \\ \text { observed winter }\end{array} & +0.39 & +0.43 & -0.29 \\ \text { balance) } & & & \end{array}$

of the three glaciers for the present climate (the 1961-90 normals) are compared to the means of the observed specific annual balances for the period 1963-90. It appears that there is a reasonable agreement between measured and model-calculated specific annual balances, particularly when the observed winter balance is used in the calculations.

Figure 8 illustrates the sensitivity to climate change of the specific mass-balance components, i.e. the total accumulation, the total ablation and the total net balance averaged over the glacier area. This figure confirms that Alfotbreen is more sensitive to climate warming than Nigardsbreen and Hellstugubreen; assuming unchanged precipitation and a temperature increase of $3 \mathrm{~K}$, the specific annual balance of Alfotbreen will change by more than $3 \mathrm{~m}_{\text {year }}{ }^{-1}$, whereas the change in specific annual balance for the other glaciers is only about 2 mear $^{-1}$. The decreasing trends of the specific annual accumulation for increasing temperature reflect that a lower proportion of the precipitation will fall as snow in a warmer climate. This will cause the annual snow precipitation to decrease by about $6 \%$ for each degree of warming, assuming the total annual precipitation is unchanged.

For small changes with respect to the present climatic conditions, the sensitivity to climate change of the specific annual balance of the three glaciers can be expressed by the following equations ( $\Delta b=$ change in net balance $\left(\right.$ mear $\left.^{-1}\right), \Delta T=$ temperature change $(\mathrm{K})$ and $\Delta p / p=$ relative change in annual precipitation):

$$
\begin{aligned}
& \text { Ålfotbreen } \Delta b=-1.04 \Delta T+3.87 \Delta p / p, \\
& \text { Nigardsbreen } \Delta b=-0.60 \Delta T+2.28 \Delta p / p, \quad(3 \mathrm{a}, \mathrm{b}, \mathrm{c}) \\
& \text { Hellstugubreen } \Delta b=-0.54 \Delta T+1.42 \Delta p / p .
\end{aligned}
$$

For larger changes, the relationships will be modified for at least two reasons: (1) as illustrated by the non-linear relationships between mass balance and temperature change shown in Figure 8, the sensitivity to climatic change will increase when the temperature change increases; (2) changes in the geometry of the glaciers due to changed mass balance and glacier dynamics are not considered in the expressions for the net-balance changes. After some years with changed mass balance, changes in glacier extent and surface elevations will become large enough to have a significant influence on the mass balance and its distribution over the glacier. This topic is being studied in a paper in preparation by $\mathrm{T}$. Jóhannesson and T. Laumann.
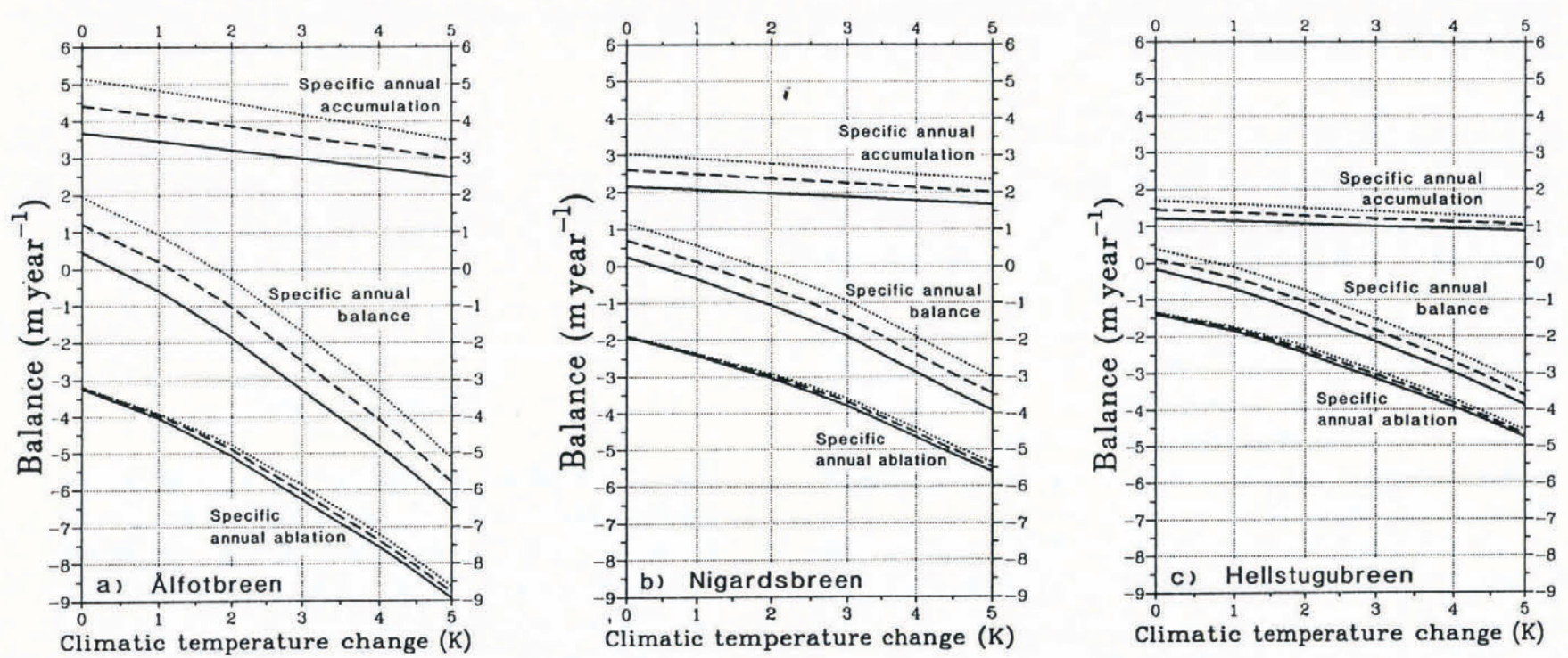

Fig. 8. Sensitivity to climate change of the specific annual accumulation, the specific annual balance and the specific annual ablation for (a) Alfotbreen, (b) Nigardsbreen and (c) Hellstugubreen. Legend: - unchanged precipitation as compared to the present; - - - $20 \%$ increase of precipitation; .... $40 \%$ increase of precipitation. 
According to Equations (3a, b, c), the specific annual balances of the three glaciers show quite different sensitivities to a temperature change as well as to changing precipitation. For example, Ảlfotbreen will react more violently both to a given temperature change and to a given precipitation change than Nigardsbreen and Hellstugubreen. The change in net balance, obviously, will depend on how much the precipitation will change when the temperature changes. This is illustrated in Figure 9, which shows the change in

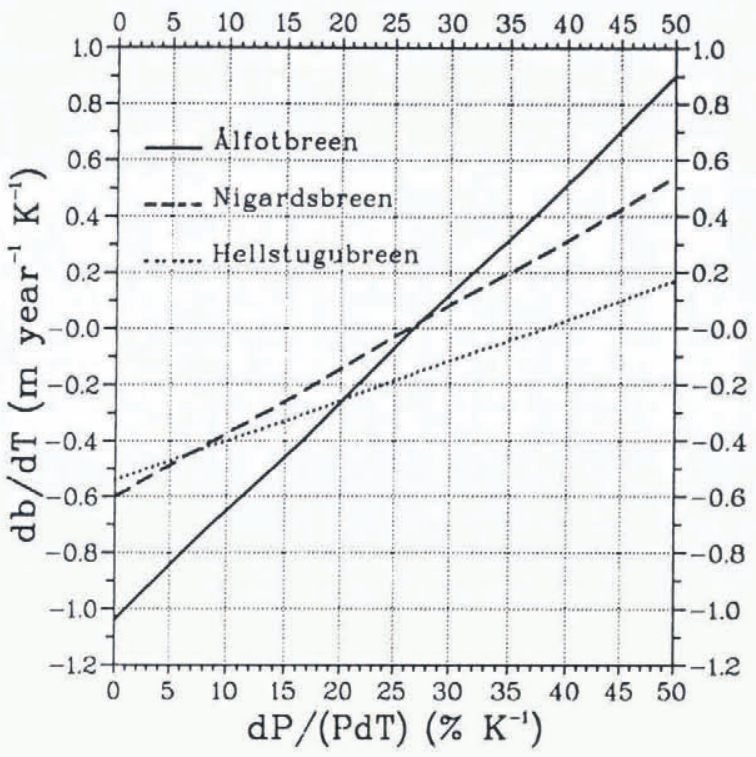

Fig. 9. Change in specific annual balance for a $1 \mathrm{~K}$ temperature increase $(\mathrm{d} b / \mathrm{d} t)$ as a function of the percentage change in precipitation per $1 K$ temperature increase $(\mathrm{d} p / P \mathrm{~d} T)$ for Alfotbreen, Nigardsbreen and Hellstugubreen.

specific annual balance for a $1 \mathrm{~K}$ temperature increase $(\mathrm{d} b / \mathrm{d} t)$ as a function of the percentage change in precipitation per $1 \mathrm{~K}(\mathrm{~d} P /(P \mathrm{~d} t))$. It appears from the figure that the specific annual balance for Hellstugubreen will decrease as long as $\mathrm{d} P /(P \mathrm{~d} t)$ is less than $38 \% \mathrm{~K}^{-1}$, whereas the corresponding limit for Alfotbreen and Nigardsbreen is about $27 \% \mathrm{~K}^{-1}$. This shows that, unless a climatic warming is accompanied by a dramatic increase of precipitation, all three glaciers will loose mass if the climate becomes warmer.

\section{CONCLUSION}

A simple degree-day model has been used to estimate the mass-balance-elevation relationship for three glaciers in Norway, based on temperature and precipitation data from nearby climate stations. The three glaciers are Ålfotbreen, Nigardsbreen and Hellstugubreen, located in a west-east transect in southern Norway.

The model is calibrated by means of the average of measured mass balances for the period 1963-90, and 30 year normals (1961-90) of meteorological data. In addition to temperature and precipitation observed at nearby climate stations, the parameters of the model are degree-day factors for snow and ice melt, and elevation gradients of temperature and precipitation. The tem- perature-elevation gradient is chosen between -0.70 and $-0.75 \mathrm{~K} / 100 \mathrm{~m}$, in accordance with observations near the glaciers. The precipitation-elevation gradient is found to be $7-8 \% / 100 \mathrm{~m}$ by fitting the model calculated snow accumulation to the observed winter balances on the glaciers, taking into account that an increasing proportion of the annual precipitation will fall as snow at high elevations due to low temperatures. The degree-day factors have been determined to vary between 3.5 and $4.5 \mathrm{~mm} \mathrm{H}_{2} \mathrm{O} \mathrm{K}^{-1} \mathrm{~d}^{-1}$ for snow melt and between 5.5 and $6.0 \mathrm{~mm} \mathrm{H}_{2} \mathrm{O} \mathrm{K}^{-1} \mathrm{~d}^{-1}$ for ice melt.

Using these values, the changed mass balance of the three glaciers is estimated for different climate scenarios. For an increase of the temperature of $1-2 \mathrm{~K}$ and an increase of the precipitation of $10 \%$, Hellstugubreen will achieve the best of the three glaciers. This is due to the fact that the glacier is located so high that a relatively high proportion of the precipitation will fall as snow even when the temperature increases. On the lower parts of Nigardsbreen, the increase in precipitation has little influence on the annual balance, because most of the increase will be in the form of rain. The glacier tongue will become steeper and dynamically more active.

If the temperature increases a few degrees more, even Hellstugubreen will experience a significant retreat, because of increased melting, but also because a higher percentage of the precipitation will fall as rain. However, a rise in the equilibrium line will have less effect for the total balance of the glacier than a similar rise in the plateau glaciers.

On the other hand, this study clearly shows that unless a climatic warming is accompanied by a dramatic increase in the precipitation (between $27 \% \mathrm{~K}^{-1}$ and $\left.38 \% \mathrm{~K}^{-1}\right)$, all three glaciers will lose mass.

\section{REFERENGES}

Braithwaite, R.J. 1985. Calculation of degree-days for glacier-climate research. Z. Gletscherkd. Glazialgeol., 20, 1984, 1-8.

Braithwaite, R.J. and O. B. Olesen. 1989. Calculation of glacier ablation from air temperature, West Greenland. In Oerlemans, J., ed. Glacier fluctuations and climatic change. Dordrecht, etc., Kluwer Academic Publishers, 219-233.

Furmyr, S. and A. Tollan. 1975. Resultater og erfaringer av undersekelser $i$ Filefjell representative omráde 1967-1974. Oslo, Den Norske IHD-komité. Sekretariatet.

Houghton, J. T., G.J. Jenkins and J.J. Ephraums, eds. 1990. Climate change. The IPCC scientific assessment. Cambridge, Cambridge University Press.

Liestøl, O. 1967. Storbreen glacier in Jotunheimen, Norway. Nor. Polarinst. Skr. 141.

Messel, S. 1985. Energibalanse-undersøkelser på breer i Norge 1954 1981. Norges Vassdrags-og Elektrisitetsvesen. Vassdragsdirektoratet. Hydrologisk Avdeling. Rapport 1-85, 45-59.

Pytte, R. and O. Liestøl. 1966. Glasio-hydrologiske undersekelser $i$ Norge 1965. Oslo, Vassdragsdirektoratet. Hydrologisk Avdeling.

Reeh, N. 1991. Parameterization of melt rate and surface temperature on the Greenland ice sheet. Polarforschung, 59(3),1989, 113-128.

Roland, E. and N. Haakensen, eds. 1985. Glasiologiske undersøkelser i Norge 1982. Norges Vassdrags- og Elektrisitetsvesen. Vassdragsdirektoratet. Hydrologisk Avdeling. Rapport 1-85.

Sælthun, N.R. and 6 others. 1990. Klimaendringer og vannressurser. Bidrag til den inter-departementale klimautredning. Norges Vassdrags- og Elektrisitetsvesen. Vassdragsdirektoratet. V-publikasjon 30.

The accuracy of references in the text and in this list is the responsibility of the authors, to whom queries should be addressed. 